\title{
Sneezing, science behind the veil
}

\begin{abstract}
Sneezing brings a person the blessing of relief by releasing thousands of germs out of the body that were trapped in the head, lungs, body which, if they were to remain there, would cause the person pain and sickness. For this reason, sneezing is considered as blessing from Allah and has well-established norms for the sneezer and the companion of the sneezer. The science if explored, would explain the body immune response against the germs and irritants that cause one to sneeze. Therefore, the combine study of Islam in relation to science would guide contemporary researchers, doctors, clinicians and biologists for thinking in lines with religious instructions and its application in science. Herein this article, few reference on the act of sneezing, its benefits, and capability of spread to others and relief to the sneezers has been related to the quoted saying of prophet Muhammad peace be upon him and explained in the terminology of modern science for the guidance of scientific community in particular and humanity in general.
\end{abstract}

Keywords: sneezing, science, islam, veil, immune response
Volume II Issue 3 - 2018

\section{Inamullah Khan}

Nuclear Institute for Food and Agriculture (NIFA), Pakistan

Correspondence: Inamullah Khan, Nuclear Institute for Food and Agriculture (NIFA), P.O. Box. 446, Pakistan,

Email inamullah17@gmail.com

Received: December 20, 2017| Published: May 09, 2018

\section{Introduction}

\section{Scientific perspective}

A sneeze is a semi-autonomous, convulsive expulsion of air from the lungs through the nose and mouth, usually caused by foreign particles irritating the nasal mucosa. ${ }^{1}$ Sneezing usually begins with the release of chemicals such as histamine or leukotrienes caused by viral respiratory infections, filtered particles, allergens (substances that trigger allergic reactions) or physical irritants such as smoke, pollution, perfumes and cold air. Allergic reactions with the nasal mucosa require the presence of IgE (allergy antibody specific for the allergen). This leads to fluid leakage from vessels in the nose, causing symptoms of congestion and nasal drip. Additionally, nerve endings are stimulated leading to the sensation of itching. ${ }^{2}$ Thus, a sneeze is a protective reaction to a nasal passage irritation or inflammation from a virus, an allergy or a bacterial infection. Despite the various outside influences causing a sneeze, the process actually starts in the nervous system. Information is sent to the brain that something in the nose, an irritant of some sort, needs to be expelled. The brain orders for propulsion of this irritant with a sneeze or a series of sneeze. ${ }^{3,4}$ Some people never sneeze just once, but several times in a row. This is due to the reason that the irritant may not be dislodged by a first sneeze but may send signals in the form of a string of histamines causing several sneezes. This propulsion can sometimes be as fast as 100 miles an hour ${ }^{5,6}$ and send thousands of germs into the air. Those with allergies may always need a few sneezes to clear the passages.

\section{Islamic perspective}

Sneezing brings a person the blessing of relief by releasing thousands of germs out of the body that were trapped in the head, lungs, body which, if they were to remain there, would cause the person pain and sickness. For this reason, sneezing is considered as blessing from Allah and in a narration ${ }^{3,4}$ from Prophet Muhammad peace and blessings of Allah be upon him who said: "When one of you sneezes, let him say, 'Al-hamdu-Lillaah' (Praise be to Allah),' and let his brother or companion reply to him. 'Yarhamuk Allaah' (May Allah have mercy on you).' If he says, 'Yarhamuk-Allaah,' (May Allah have mercy on you) then let (the sneezer) say, 'Yahdeekum Allaah wa yuslihu baalakum (May Allah guide you and rectify your condition)."

\section{Conclusion}

People at the time of Muhammad (peace and blessings of Allah be upon him) were not aware of the science behind the body immune response against the germs and irritants that caused one to sneeze. However, the prophet of mercy via Divine revelations guided his believers (the sneezing person) to praise Allah for the blessing of enabling his body immune system to react against the intruding germs and irritants by expelling them through sneezing. When a person sneezes, this is an indication of good health, and sound immune system and physical strength, so he should thank Allah by praising 'Al-hamdu-Lillah'. The guidance given to the person who is close to the sneezer to say, (May Allah have mercy on you) is again according to etiquettes, good feelings and scientific norms for the companion to pray for the better defense system of the sneezer against the germs. Hearing this, the sneezer should reply as explained in the quoted saying of Muhammad (peace be upon him) again to the companion by saying (May Allah guide you and rectify your condition) to pray him back even with more polite and attractive words of refinement for having strong responsive immune system if companion was lacking any against similar germs. Thus no state of a believer is out of reward even by sneezing, and hearing of sneezing, there is much to gain and fill up the Book of Deeds with rewards even with this minor action if done for pleasing Allah and his prophet.

\section{Acknowledgments}

None

\section{Conflict of interest}

Author declares there is no conflict of interest. 


\section{References}

1. https://en.wikipedia.org/wiki/Sneeze

2. Why do we sneeze? - Scientific American https://www.scientificamerican com/article/why-do-we-sneeze/

3. https://muflihun.com/muslim/1/243
4. Imam al-Bukhaari in al-Adab al-Mufrad (5033).

5. http://www.nbcnews.com/watch/nbc-news/the-science-ofsneezing-388168771913

6. https://www.decodedscience.org/science-sneezing-healthy-sneeze/55989 